\title{
Epidemiological Study of Iron Deficiency Anemia Among Youth Female Athletes in Kuwait
}

\author{
Mahmoud Ali Saleh ${ }^{1}$, Abdo Salama Abdo ${ }^{1}$, Rasha Shaker Eldesouky ${ }^{1}$, Mona Ahmed El-Awady ${ }^{1}$ and Mai Shaker \\ Almaghrabi ${ }^{2 *}$
}

${ }^{1}$ Public health and Community Medicine, Faculty of Medicine, Benha University, Egypt

${ }^{2}$ Registrar in Sport medicine and Health awareness Center, Public authority for sport and youth, Kuwait

Received: 制August 28, 2018; Published: 制 September 04, 2018

*Corresponding author: Mai Shaker Mahmoud Almaghrabi, master's in public health and Preventive Medicine, Alexandria

University, Registrar in Sport medicine and Health awareness Center, Public authority for sport and youth, Kuwait

\begin{abstract}
Background: The prevalence of iron deficiency anemia is likely to be higher in athletic populations and groups, especially in younger female
\end{abstract} athletes, than in healthy sedentary individuals.

Aim: of this study is to determine the magnitude of this problem among athletes and identify their different dietary habits.

Subjects and Methods: Across sectional study was done. The sample included 150 female players from the female clubs in Kuwait where almost all types of sports activity are practiced at level of national competition. Using structured assisted questionnaire with laboratory investigations.

Results: Fifty five percent of anemic group were non-Kuwaiti, with a statistically significant difference. There was a statistically significant difference between the anemic, iron deficient and normal groups regarding the marital status and occupation, dietary pattern and habits as intake of tea and soft drinks. There were highly statistical significant differences between the three studied groups regarding blood hemoglobin (Hb), Mean corpuscular volume (MCV), Mean corpuscular hemoglobin (MCH), Mean corpuscular hemoglobin concentration (MCHC) and Serum ferritin.

Conclusion: A significant relation between dietary habits of female athlete. Also the logistic regression analysis reveals that increased number of soft drinks and tea drinks per day is significantly associated with high probability of having anemia. Women with increased consumption of soft drinks per day and those with high tea consumption per day are more than two times at higher risk of anemia (OR=2.34 and 2.17 respectively). On the other hand, Kuwaiti nationality, increased duration of practicing sport and increased frequency of eating breakfast in the last month subjects are significantly associated with lower probability of having anemia $(\mathrm{OR}=0.14,0.74$ and 0.17 respectively).

Keywords: Female Athletes; Iron Deficiency; Dietary Iron; Metabolism and Bioavailability; Stages of Iron Deficiency; Dietary Pattern and Habits; Predisposing Factors to Iron Deficiency Anemia

\section{Introduction}

Anemia is the most common disorder of the blood, affecting about quarter the people worldwide [1]. It is usually defined as a decrease in amount of red blood cells (RBCs) or hemoglobin in the blood [2,3] Iron-deficiency anemia is the greatest common type of anemia. It happens when the body does not have enough iron. Iron deficiency is typically due to blood loss but may infrequently be due to poor absorption of iron. Pregnancy and childbirth consume a great deal of iron and thus can cause pregnancy-related anemia. Individuals who have had gastric bypass surgery for weight reduction or other reasons may also be iron deficient due to weak absorption [4]. Female athletes are considered to be at a greater risk of compromised iron status which may lead to iron deficiency (with or without anemia) due to negative iron balance contributed by insufficient dietary iron intake, menstruation, increased iron losses associated with haemolysis, sweating, gastrointestinal bleeding and exercise induced acute inflammation [5,6]. Iron plays an important role in oxygen transport and fuel consumption [7]. Iron is crucial for the synthesis of hemoglobin and myoglobin, the proteins that carry oxygen to the blood and muscle, respectively. It is a vital component of the electron transport system that controls the energy release from cells. Iron is involved in DNA synthesis and red blood cell production. It acts as a promoter against harmful free-radical production [8]. But still wondering how exactly this mineral affects peak physical performance and when an athlete functions without adequate iron, less oxygen is transported to the muscles, maximal oxygen consumption $\left(\mathrm{VO}_{2} \max \right)$ falls, and physical 
performance is affected [9]. Moreover, too little iron may weaken immune and other physiological functions [10].

Iron deficiency is a progressive condition that develops through three stages: iron depletion, iron deficiency and iron deficiency anemia [11]. Iron deficiency is more common among physically active individuals compared with their sedentary counterpart. There are a few reasons why athletes are at a higher risk of experiencing iron deficiency compared to their non-athletic counterparts as higher requirements for iron use and increased risk of iron loss $[12,13]$.

The aim of this study was to determine the magnitude of the iron deficiency and iron deficiency anemia among female Kuwaiti athletes and identify their different dietary habits.

\section{Patients and Methods}

A cross sectional study was done. Based on recent figure about the prevalence of iron deficiency anemia (IDA) among female athletes to be $10 \%$ [14]. The minimum sample size was calculated to be $139\left(\mathrm{~N}=\mathrm{Z}^{2} \times \mathrm{PQ} / \mathrm{E}^{2}=(1.96)^{2} \times 0.10 \times 0.97 /(0.05)^{2}=139\right)$ out of the total 321 female athletes registered. The sample was increased to 150 players from the three female clubs in Kuwait (Aloyoun sport club, Salwa Alsabah sport club and Alfatat sport club) where almost all types of sports activity are practiced at level of national competition to increase accuracy of the results. Players fulfilling the inclusion criteria and accepted to participate were included. A random group of 150 female athletes were selected from a population of 321 using random systematic sampling technique.

Data were collected from the sample's athletes using a structured assisted questionnaire which included personal sociodemographic characteristics and history of following diet. In addition, dietary habits of the athletes, the components of athletes`meals, as well as drinking tea, coffee and soft drinks. Smoking, medical history, family medical history (as diabetes and hypertension) and gynecological history were also included. Finally, a detailed description of the practiced sport. Physical examinations as anthropometric measurements (weight, height, waist circumference and calculating body mass index), medical examination which include blood pressure, signs of anemia, abdominal examination and blood investigations [15] (hemoglobin, $\mathrm{MCV}, \mathrm{MCH}, \mathrm{MCHC}$ and serum ferritin).

The collected data were summarized in terms of mean \pm Standard Deviation (SD) and range for quantitative data and frequency and percentage for qualitative data. Comparisons between the different study groups were carried out using the Chisquare $\left(\chi^{2}\right)$ and Fisher's Exact Test (FET) to compare proportions as appropriate. The student t-test $(t)$ was used to compare differences in the mean between two groups regarding normally distributed data. Stepwise logistic regression of being anemic conditioned on potential risk factors was carried out to identify significant factors and the results were expressed as Odd Ratio (OR) and 95\% Confidence Interval (CI). Statistical significance was accepted at P value $<0.05$ (S). A $\mathrm{P}$ value $<0.001$ was considered highly significant (HS) while a $\mathrm{P}$ value $>0.05$ was considered nonsignificant. All statistical analyses were carried out using STATA/SE version 11.2 for Windows (STATA Corporation, College Station, Texas).

\section{Results}

The study revealed that (14.7\%) of the subjects included had a low hemoglobin value and low serum ferritin that were classified as being iron deficiency anemia (IDA). (36.7\%) had a normal hemoglobin value and low serum ferritin that were classified as being iron deficient (ID) while the rest of the participants were classified as being normal (48.7\%) (Table 1$)$.

Table 1: Prevalence of IDA, ID and being normal among studied groups.

\begin{tabular}{|c|c|c|}
\hline Group (no.=150) & No. & \% \\
\hline *IDA (below normal Hb \& below normal ferritin) & 22 & 14.7 \\
\hline${ }^{*}$ ID (normal Hb \& below normal ferritin) & 55 & 36.7 \\
\hline Normal (normal Hb \& normal ferritin) & 73 & 48.7 \\
\hline
\end{tabular}

IDA: Iron Deficiency Anemia

ID: Iron Deficient

$\mathrm{Hb}$ : blood hemoglobin

*This criteria according to German et al. [16].

Table 2: Comparing IDA, ID and normal groups according to sociodemographic characteristics.

\begin{tabular}{|c|c|c|c|c|c|c|c|c|c|}
\hline \multirow{2}{*}{\multicolumn{2}{|c|}{ Variable }} & \multicolumn{2}{|c|}{$\begin{array}{c}\text { IDA } \\
\text { (no.=22) }\end{array}$} & \multicolumn{2}{|c|}{$\begin{array}{c}\text { ID } \\
\text { (no.=55) }\end{array}$} & \multicolumn{2}{|c|}{ Normal (no.=73) } & \multirow{3}{*}{$\begin{array}{c}\begin{array}{c}\text { Chisquare } \\
\text { Test }\end{array} \\
12.48 \\
\end{array}$} & \multirow{3}{*}{$\begin{array}{c}\mathbf{P} \\
<0.05\end{array}$} \\
\hline & & \multirow{2}{*}{$\begin{array}{c}\text { No. } \\
10\end{array}$} & \multirow{2}{*}{$\begin{array}{c}\% \\
45.5\end{array}$} & \multirow{2}{*}{$\begin{array}{l}\text { No. } \\
45\end{array}$} & \multirow{2}{*}{$\begin{array}{c}\% \\
81.8\end{array}$} & \multirow{2}{*}{$\begin{array}{c}\text { No. } \\
58\end{array}$} & \multirow{2}{*}{$\begin{array}{c}\% \\
79.5\end{array}$} & & \\
\hline Nltipnliti & Kuwaiti & & & & & & & & \\
\hline iNationdinty & Non-Kuwaiti & 12 & 54.6 & 10 & 18.2 & 15 & 20.6 & & \\
\hline Age (years) & Mean \pm SD & \multicolumn{2}{|c|}{$18.95 \pm 3.41$} & \multicolumn{2}{|c|}{$18.8 \pm 3.05$} & \multicolumn{2}{|c|}{$18.54 \pm 2.86$} & $\mathrm{~F}=0.21$ & $>0.05$ \\
\hline
\end{tabular}




\begin{tabular}{|c|c|c|c|c|c|c|c|c|c|}
\hline \multirow{2}{*}{$\begin{array}{l}\text { Marital } \\
\text { status }\end{array}$} & Single & 17 & 77.3 & 50 & 90.9 & 70 & 95.9 & \multirow{2}{*}{ FET } & \multirow{2}{*}{$<0.05$} \\
\hline & Married & 5 & 22.7 & 5 & 9.1 & 3 & 4.1 & & \\
\hline \multirow{5}{*}{$\begin{array}{c}\text { Educational } \\
\text { level }\end{array}$} & Primary & 1 & 4.6 & 0 & 0 & 0 & 0 & \multirow{5}{*}{ FET } & \multirow{5}{*}{$>0.05$} \\
\hline & intermediate & 4 & 18.2 & 3 & 5.5 & 3 & 4.1 & & \\
\hline & Secondary & 10 & 45.5 & 25 & 45.5 & 36 & 49.3 & & \\
\hline & Diploma & 5 & 22.7 & 9 & 16.4 & 17 & 23.3 & & \\
\hline & University & 2 & 9.1 & 18 & 32.7 & 17 & 23.3 & & \\
\hline \multirow{4}{*}{ Occupation } & Student & 11 & 50 & 44 & 80 & 58 & 79.5 & \multirow{4}{*}{ FET } & \multirow{4}{*}{$<0.05$} \\
\hline & No work & 7 & 31.8 & 4 & 7.3 & 2 & 2.7 & & \\
\hline & Employee & 2 & 9.1 & 3 & 5.5 & 6 & 8.2 & & \\
\hline & Technician & 2 & 9.1 & 4 & 7.3 & 7 & 9.6 & & \\
\hline
\end{tabular}

F: Oneway Analysis of Variance (ANOVA)

P: Probability

Significant $(\mathrm{P}<0.05)$

Non-significant $(\mathrm{P}>0.05)$

FET: Fisher Exact Test

IDA: iron deficiency anemia

ID: iron deficiency

Regarding the sociodemographic characteristic, more than half of anemic (54.6\%) were non-Kuwaiti. The majority of iron deficient $(81.8 \%)$ and of normal $(79.5 \%)$ were Kuwaiti with statistically significant difference $(\mathrm{P}<0.05)$. There was a statistically significant difference between the three groups regarding the marital state and occupation $(\mathrm{P}<0.05)$ for all. But insignificant difference regarding the mean age and the educational level $(\mathrm{P}>0.05)$ (Table 2).
Regarding the dietary pattern and habits between the three groups more than two thirds $(68.2 \%)$ of the iron deficient anemic participants had two or less meals per day while more than half of iron deficient group (58.2\%) compared to the majority of normal athletes $(89 \%)$ consumed more than two meals per day. This difference is statistically significant $(\mathrm{P}<0.001)$ (Table 3$)$.

Table 3: Comparing IDA, ID and normal groups regarding the dietary pattern and habits.

\begin{tabular}{|c|c|c|c|c|c|c|c|c|c|}
\hline \multicolumn{2}{|c|}{ Variable } & \multicolumn{2}{|c|}{$\begin{array}{c}\text { IDA } \\
\text { (no.=22) }\end{array}$} & \multicolumn{2}{|c|}{$\begin{array}{c}\text { ID } \\
(\text { no. }=55)\end{array}$} & \multicolumn{2}{|c|}{ Normal (no.=73) } & \multirow{2}{*}{$\begin{array}{c}\text { Chisquare } \\
\text { Test }\end{array}$} & \multirow[t]{2}{*}{$\mathbf{P}$} \\
\hline & & No. & $\%$ & No. & $\%$ & No. & $\%$ & & \\
\hline \multirow{2}{*}{$\begin{array}{c}\text { No. of } \\
\text { meals/day }\end{array}$} & $\leq 2$ & 15 & 68.2 & 23 & 41.8 & 8 & 11 & \multirow{2}{*}{31.11} & \multirow{2}{*}{$<0.001$} \\
\hline & $>2$ & 7 & 31.8 & 32 & 58.2 & 65 & 89 & & \\
\hline \multirow{3}{*}{$\begin{array}{c}\text { Breakfast } \\
\text { in the last } \\
\text { month }\end{array}$} & Never & 11 & 50 & 14 & 25.5 & 7 & 9.6 & \multirow{3}{*}{25.73} & \multirow{3}{*}{$<0.001$} \\
\hline & Most of days & 11 & 50 & 17 & 30.9 & 31 & 42.5 & & \\
\hline & Always & 0 & 0 & 24 & 43.6 & 35 & 48 & & \\
\hline \multirow{4}{*}{$\begin{array}{l}\text { No. of soft } \\
\text { drinks/day }\end{array}$} & 0 & 3 & 13.6 & 16 & 29.1 & 37 & 51.4 & \multirow{3}{*}{20.92} & \multirow{3}{*}{$<0.001$} \\
\hline & 1 & 4 & 18.2 & 22 & 40 & 17 & 23.6 & & \\
\hline & $\geq 2$ & 15 & 68.2 & 17 & 30.9 & 19 & 26 & & \\
\hline & Mean \pm SD; (range) & \multicolumn{2}{|c|}{$2.23 \pm 1.57 ;(0-7)$} & \multicolumn{2}{|c|}{$1.16 \pm 1.05 ;(0-4)$} & \multicolumn{2}{|c|}{$0.92 \pm 1.26 ;(0-5)$} & $\mathrm{F}=9.44$ & $<0.001$ \\
\hline \multirow{4}{*}{$\begin{array}{l}\text { No. of tea } \\
\text { drinks/day }\end{array}$} & 0 & 10 & 45.5 & 32 & 58.2 & 44 & 61.1 & \multirow{3}{*}{15.64} & \multirow{3}{*}{$<0.05$} \\
\hline & 1 & 2 & 9.1 & 8 & 14.6 & 21 & 29.2 & & \\
\hline & $\geq 2$ & 10 & 45.5 & 15 & 27.3 & 8 & 11 & & \\
\hline & Mean \pm SD; (range) & \multicolumn{2}{|c|}{$1.32 \pm 1.43 ;(0-4)$} & \multicolumn{2}{|c|}{$0.71 \pm 0.92 ;(0-3)$} & \multicolumn{2}{|c|}{$0.49 \pm 0.67 ;(0-2)$} & $\mathrm{F}=7.11$ & $<0.05$ \\
\hline \multirow{4}{*}{$\begin{array}{l}\text { No. of coffee } \\
\text { drinks/day }\end{array}$} & 0 & 11 & 50 & 24 & 43.6 & 31 & 43.1 & \multirow{3}{*}{5.81} & \multirow{3}{*}{$>0.05$} \\
\hline & 1 & 5 & 22.7 & 10 & 18.2 & 25 & 34.7 & & \\
\hline & $\geq 2$ & 6 & 27.3 & 21 & 38.2 & 17 & 23.3 & & \\
\hline & Mean \pm SD; (range) & \multicolumn{2}{|c|}{$0.82 \pm 0.96 ;(0-3)$} & \multicolumn{2}{|c|}{$1.18 \pm 1.28 ;(0-4)$} & \multicolumn{2}{|c|}{$0.8 \pm 0.82 ;(0-3)$} & $F=2.28$ & $>0.05$ \\
\hline
\end{tabular}




\begin{tabular}{|c|c|c|c|c|c|c|c|c|c|}
\hline \multirow{3}{*}{ Smoking } & No & 20 & 90.9 & 55 & 100 & 71 & 97.3 & \\
\cline { 2 - 9 } & Yes & 0 & 0 & 0 & 0 & 1 & 1.4 & \multirow{2}{*}{ FET } & $>0.05$ \\
\cline { 2 - 9 } & Exsmoker & 2 & 9.1 & 0 & 0 & 1 & 1.4 & \\
\hline
\end{tabular}

P: Probability

Significant $(\mathrm{P}<0.05)$

Highly Significant $(\mathrm{P}<0.001)$

Non-significant $(\mathrm{P}>0.05)$

FET: Fisher Exact Test

F: Oneway Analysis of Variance (ANOVA)

IDA: Iron Deficiency Anemia

ID: Iron Deficient

Table 3 also shows that exactly half (50\%) of the IDA group never had breakfast and the other half had breakfast most of the days in last month. In the iron deficient and normal groups, the highest percentage for those who always had breakfast in the last month (43.6\% and $48 \%$ respectively). This difference is statistically significant $(\mathrm{P}<0.001)$. There was a highly statistically significant difference regard the number of soft drinks $(\mathrm{P}<0.001)$ and tea cups consumed daily $(\mathrm{P}<0.05)$.

A highly statistical significant differences between the anemic, iron deficient and normal groups regarding blood hemoglobin ( $\mathrm{Hb})$,
Mean corpuscular volume (MCV), Mean corpuscular hemoglobin $(\mathrm{MCH})$, Mean corpuscular hemoglobin concentration (MCHC) and Serum ferritin $(\mathrm{P}<0.001$ in all items). The mean hemoglobin $(\mathrm{Hb})$ level among the IDA group was $11.07 \pm 0.63 \mathrm{gm} / \mathrm{dl}$ while it was $13.03 \pm 0.98 \mathrm{gm} / \mathrm{dl}$ among ID group and $13.41 \pm 0.78 \mathrm{gm} / \mathrm{dl}$ among normal group. Regard the mean serum ferritin level among IDA, ID and normal participants was $12.01 \pm 6.13 \mathrm{ng} / \mathrm{ml}, 18.87 \pm 6.04 \mathrm{ng} /$ $\mathrm{ml}$ and $43.38 \pm 12.67 \mathrm{ng} / \mathrm{ml}$ respectively (Table 4). All participants of the anemic and non-anemic groups had normal CRP levels (CRP negative).

Table 4: Comparing IDA, ID and normal groups according to the different laboratory investigations.

\begin{tabular}{|c|c|c|c|c|c|c|c|c|c|c|c|}
\hline \multirow{2}{*}{ Variable } & \multicolumn{3}{|c|}{ IDA (no.=22) } & \multicolumn{3}{|c|}{ ID (no.=55) } & \multicolumn{3}{|c|}{ Normal (no.=73) } & \multirow{2}{*}{$\mathbf{F}$} & \multirow{2}{*}{$\mathbf{P}$} \\
\hline & Mean & SD & Range & Mean & SD & Range & Mean & SD & Range & & \\
\hline $\mathrm{HB}(\mathrm{gm} / \mathrm{dl})$ & 11.07 & 0.63 & $10-11.9$ & $\dagger 13.03$ & 0.98 & $12-15.3$ & $\dagger \neq 13.41$ & 0.78 & $12-15.3$ & 65.41 & $<0.001$ \\
\hline $\mathrm{MCV}(\mathrm{fl})$ & 74.7 & 5.2 & $67-88.5$ & $\dagger 84.8$ & 4.69 & $76.7-93.5$ & $† 86.05$ & 3.4 & $78.7-94$ & 63.27 & $<0.001$ \\
\hline $\mathrm{MCH}(\mathrm{pg})$ & 24.77 & 2.23 & $21.5-30$ & $\dagger 30.05$ & 7.95 & $24-86.4$ & $\dagger 29.22$ & 1.67 & $26.3-33.3$ & 8.95 & $<0.001$ \\
\hline $\mathrm{MCHC}(\mathrm{gm} / \mathrm{l})$ & 326.82 & 5.31 & $317-337$ & $† 335.87$ & 7.92 & $313-351$ & $† 337.42$ & 8.01 & $309-352$ & 16.45 & $<0.001$ \\
\hline Serum ferritin (ng/ml) & 12.01 & 6.13 & $4-31.2$ & $\dagger 18.87$ & 6.04 & $9-29.8$ & $\dagger \neq 43.38$ & 12.67 & $30-77$ & 138.19 & $<0.001$ \\
\hline
\end{tabular}

P: Probability

Significant $(\mathrm{P}<0.05)$

Highly Significant $(\mathrm{P}<0.001)$

F: Oneway Analysis of Variance (ANOVA) † Significant differences compared to anemic group $\ddagger$ Significant differences compared to iron deficient group

Table 5: Logistic regression analysis for being anemic athletes conditioned on significant risk factors.

\begin{tabular}{|c|c|c|c|}
\hline Variable (no.=150) & OR & $\mathbf{9 5 \%}$ CI & P \\
\hline $\begin{array}{c}\text { Nationality } \\
\text { (Kuwaiti vs. non-Kuwaiti) }\end{array}$ & 0.14 & 0.04 to 0.53 & 0.003 \\
\hline $\begin{array}{c}\text { Duration of practicing sport (years) } \\
\begin{array}{c}\text { Eating breakfast in the last month* } \\
\text { (never/most of days/ always) }\end{array}\end{array}$ & 0.74 & 0.58 to 0.96 & 0.02 \\
\hline No. of soft drinks/day & 0.17 & 0.06 to 0.48 & 0.001 \\
\hline No. of tea drinks/day & 2.34 & 1.43 to 3.84 & 0.001 \\
\hline
\end{tabular}

* A continuous variable was used to indicate a trend

OR: Odd Ratio

95\% CI: 95\% Confidence Interval 


\section{Discussion}

From the total female athletes aged (15-25), engaged in this research (36.7\%) had ID, (14.7\%) had ID anemia and (48.7\%) were normal. No previous studies done on Kuwaiti athletes to determine the prevalence of ID or IDA, it is the first study done to determine the magnitude of this problem among athletes. In 2015, a study assessed the prevalence of anemia and iron deficiency of a nationally representative sample of the Kuwait population but not athletes, reported that ID and IDA are prevalent in Kuwait $[16,17]$.

A significant percentage (54.6\%) of anemic female athletes included in this study were non Kuwaiti $(\mathrm{P}<0.001)$. Similar work done in 2004 [18] reported that the race plays a role in developing iron deficiency anemia. A significant percentage (81.8\%) of Kuwaiti participants had only iron deficient compared to non-Kuwaiti. Many studies documented that the incidence of iron deficiency without anemia is greater in female athletes [18-20]. Firstly, the Kuwaiti's habits of intake fast food and food that inhibits iron absorption as milk and milk products [17]. Secondary, the fact that iron absorption, which occurs mostly in the jejunum, is only 5 to $10 \%$ of dietary intake in persons in homeostasis, in states of overload absorption decreases [19]. Also, Kuwaiti's food supply is widely available and highly subsidized. Excessive calories are widely consumed, as evidenced by the estimated $40 \%$ obesity rate for Kuwait and it is often poor in iron [20].

The marital state and occupation had a significant relation $(\mathrm{P}<0.05$ each) and insignificant relation between the level of education $(\mathrm{P}>0.05)$ and the IDA, ID and normal groups. These factors reflect the psychological and the social state of the participant females which in turn affect their dietary habits and predisposing to ID and IDA. These results are in agreement with similar work done in 2004 [21] by Jolie reported a positive relation between anemia, education level and occupation. On the contrary, a study done in Kuwait [22] reported that the prevalence of anemia and ID did not differ by level of education or income. Also there was no significant relation between ID, IDA or normal and age of the participants $(\mathrm{P}>0.05)$. However, a study done in Bangladesh in 2005 showed that the prevalence of anemia varied by age and gender, but not socioeconomic status [23].

The study shows a significant good iron state and iron intake, assessed as the number of meals per day and the frequency of eating breakfast, in the non-anemic athletes $(\mathrm{P}<0.001)$ each. ID and IDA in the anemic group is due to the change of their dietary pattern, as there was insignificant difference between the three groups regarding the history of other diseases. Also, a significant difference between IDA and ID athletes and the non-anemic group, regarding consumption the non heme iron and hem iron inhibitors or enhancers. Many researches explained the prevalence of ID and IDA in sport individuals is due to dietary pattern [24-27].
The incidence of anemia is similar in anemic and non-anemic participants across all sports with insignificant difference between the two groups regarding the duration and time of practicing the sport. Supported by the work done by Haff and Triplett in 2015 [28]. On the contrary, other studies reported anemia more in runners and football players ("foot strike hemolysis") [29,30].

A highly statistical significant differences between the three groups regarding blood hemoglobin ( $\mathrm{Hb}), \mathrm{MCV}, \mathrm{MCH}$ and $\mathrm{MCHC}$ $(\mathrm{P}<0.001)$ for all items indicating the presences of hypochromic microcytic anemia. Sport anemia that occurs in trained athletes, particularly in endurance sports because athletes have an increased total mass of red blood cells and hemoglobin in circulation relative to sedentary individuals. For defining anaemia, the cut off level of $120 \mathrm{~g} / \mathrm{L}$ set by the World Health Organization 2004 [31] using $\mathrm{Hb}$ level in combination with erythrocyte indices (MCV, MCH and $\mathrm{MCHC}$ [32].

\section{Conclusion}

IDA is more prevalent in non-Kuwaiti athletes that may be related to racial factors. ID and IDA are associated mainly with the dietary habits of the participants, the number of meals per day, the frequency of eating breakfast and type of food consumed.

\section{Recommendations}

Regular sessions of health education for athletic females about iron deficiency anemia, and factors enhancing and inhibiting it. The annual screening for all female athletes, using the traditional markers for ID and IDA; hemoglobin, MCV, MCH, MCHC, serum ferritin and TIBC.

\section{References}

1. McLean E, Cogs well M, Egli I, Wojdyla D, de Benoist B (2009) Worldwide prevalence of anaemia, WHO Vitamin and Mineral Nutrition Information System, 1993-2005. Public Health Nutr 12(4): 444-454.

2. Rodak FB, Fritsma GA, Keohane E (2007) Hematology: Clinical principles and applications ( $3^{\text {rd }}$ Edn.); Philadelphia: Saunders pp. 220.

3. Stedman, Thomas Lathrop (2006) Stedman's medical dictionary $\left(28^{\text {th }}\right.$ Edn.); Philadelphia.

4. Kumar V, Abbas AK, Fausto N, Mitchell RN (2007) Robbins Basic Pathology ( $8^{\text {th }}$ Edn.); Saunders Elsevier pp. 432.

5. McClung JP, Gaffney-Stomberg E, Lee JJ (2014) Female athletes: A population at risk of vitamin and mineral deficiencies affecting health and performance. J Trace Elem Med Biol 28(4): 388-392.

6. Clenin G, Cordes M, Huber A, Schumacher YO, Noack P, et al. (2015) Iron deficiency in sports-definition, influence on performance and therapy. Swiss Med Wkly pp. 145.

7. Schumacher YO, Schmid A, Konig D, Berg A (2002) Effects of exercise on soluble transferrin receptor and other variables of the iron status. Br J Sports Med 36(3): 195-199.

8. Burke L, Deakin V (2015) Clinical Sports Nutrition. 2000 Australia: McGraw-Hill.

9. Rockwell M, Hinton P (2005) Understanding iron. Training \& Conditioning 15(8): 19-25. 
10. Beard J, Tobin B (2000) Iron status and exercise. Am J of Clin Nutr 72(2): 594-597.

11. Janz TG, Johnson RL, Rubenstein SD (2013) Anemia in the emergency department: Evaluation and treatment. Emerg Med Pract 15(11): 1-15.

12. Alaunyte L, Stojceska V, Plunkett A (2015) Iron and the female athlete: A review of dietary treatment methods for improving iron status and exercise performance. J Int Soc Sports Nutr 12: 38.

13. Cappellini A, Motta I (2015) Anemia in Clinical Practice-Definition and Classification: Does Hemoglobin Change with Aging. Semin Hematol 52(4): 261-269.

14. Thomas Rowland (2012) Iron deficiency in athletes: An update. Am J Lifestyle Med 6(4): 319-327.

15. Nagy Mikhail, Stephen Shea, Jana Raskova, Frederick C Skvara (2005) Case-Based Pathology and Laboratory Medicine. Wilkey-Blackwell publishing p. 1-2.

16. Clénin GE, Cordes M, Huber A, Schumacher YO, Noac P, et al. (2016) Iron deficiency in sports - definition, influence on performance and therapy Review article. Swiss Sports \& Exercise Medicine 64(1): 6-18.

17. Al Zenki S, Alomirah H, Al Hooti S, Al Hamad N, Jackson RT, et al. (2015) Prevalence and Determinants of Anemia and Iron Deficiency in Kuwait Int J Environ Res Public Health 12(8): 9036-9045.

18. Ramakrishnan U, Frith-Terhune A, Cogswell M, Kettel Khan L (2002) Dietary intake does not account for differences in low iron stores among Mexican American and non-Hispanic white women: Third National Health and Nutrition Examination Survey, 1988-1994. J Nutr 132(5): 996-1001.

19. Shersten killip, John M Bennett, Mara D Chambers (2007) Iron Deficiency Anemia. Am Fam Physicians 75(5): 671-678.

20. Ahmed F, Al-Somaie MA (2010) Iron deficiency and iron deficiency anemia among pregnant women in Kuwait. Int J Food Sci Nutr 62: 585592.

21. Holschen JC (2004) The female athlete. Southern medical journal 97(9): 852-859.

\section{ISSN: 2574-1241}

DOI: 10.26717/BJSTR.2018.08.001689

Mai Shaker Almaghrabi. Biomed J Sci \& Tech Res

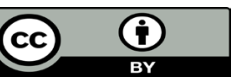

This work is licensed under Creative Commons Attribution 4.0 License

Submission Link: https://biomedres.us/submit-manuscript.php
22. Ramadan J, Vuori I, Lankenau B, Schmid T, Pratt M (2010) Developing a national physical activity plan: The Kuwait example. Glob Health Promot 17(2): 52- 57.

23. Ahmed F, Khan MA, Akhtaruzzaman M, Karim R, Marks GC, et al. (2005) Efficacy of twice-weekly multiple micronutrient supplementation for improving the hemoglobin and micronutrient status of anemic adolescent schoolgirls in Bangladesh. Am J Clin Nutr 82(4): 829-835.

24. Latunde-Dada GO (2013) Iron metabolism in athletes- achieving a gold standard. Eur J Haematol 90(1): 10-15.

25. De Andrade Cairo RC, Rodrigues Silva L, Carneiro Bustani N, Ferreira Marques CD (2014) Iron deficiency anemia in adolescents: A literature review. Nut Hosp 29(6): 1240-1249.

26. Sinclair LM, Hinton PS (2005) Prevalence of iron deficiency with and without anemia in recreationally active men and women. J Am Diet Assoc 105(6): 975-978.

27. Leonard AJ, Chalmers KA, Collins CE, Patterson AJ (2014) A Study of the Effects of Latent Iron Deficiency on Measures of Cognition: A Pilot Randomised Controlled Trial of Iron Supplementation in Young Women. Nutrients 6(6): 2419-2435.

28. G Gregory Haff, N Travis Triplett (2016) Essentials of strength training and conditioning ( $4^{\text {th }}$ Edn.); Human kinetics.

29. Dubnov G, Constantini NW (2004) Prevalence of iron depletion and anemia in top-level basketball players. Int J Sport Nutr Exerc Metab 14(1): 30-37.

30. JN Muneshwar, MS Baig, Deepali kaderkar, Khan ST, Shubhangi Deshmane (2013) Assessment of anaemia in football players: An observational Study. IOSR Journal of Dental and Medical Science (IOSRJDMS) 8(5): 6466.

31. World Health Organization TUNCsF, United Nations University (2004) Iron deficiency anaemia: Assessment, prevention, and control.

32. Pasricha SR, Low M, Thompson J, Farrell A, De-Regil LM (2014) Iron Supplementation benefits physical performance in women of reproductive age: A systematic review and meta-analysis. J Nutr 144(6): 906-914.

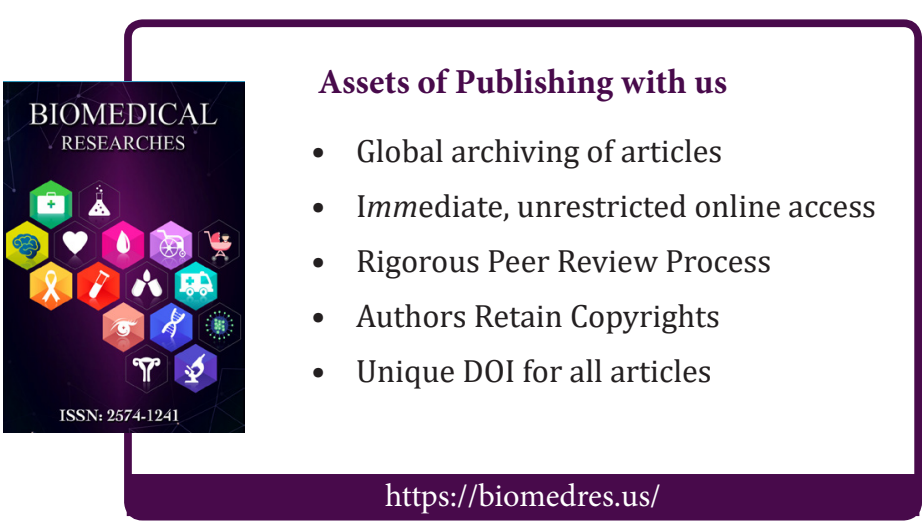

